\title{
A portrait of the South African woman manager
}

\author{
Sandra van der Merwe
}

Women who are currently in responsible management positions provide role models and valuable feedback for the future management development of womanpower in South Africa. This article, based on replies received in a national survey of women who have management and executive status in corporations, presents an overview of South African women managers. Who are they? How do they tend to think? What kind of work areas and habits do they have? How do they explain their own success and the failure of other women to reach the top? And what is important to them in their day-to-day working lives? The data collected in this project have exposed some interesting trends - useful as indicators for management, for women in careers and for parties, academic and other, intent on continuing work in this research area.

S. Afr, J. Bus. Mgmt 1979, 10:57-63

Vrouens wat tans verantwoordelike bestuursposte beklee, is rolmodelle en gee waardevolle terugvoering vir die toekomstige ontwikkeling van vrouekrag in Suid-Afrika. Hierdie artikel, wat gebaseer is op antwoorde ontvang in 'n landswye opname van vrouens wat bestuurs- en uitvoerende status in maatskappye het, gee 'n oorsig van Suid-Afrikaanse vroue-bestuurders. Wie is hulle? Hoe is hulle geneig om te dink? Watter soort werkareas en -gewoontes het hulle? Hoe verklaar hulle hul eie sukses en die mislukking van ander vrouens om die top te bereik? En wat is belangrik in hulle daaglikse werklewens? Die data in hierdie projek versamel, het interessante tendense blootgelê - nuttig as aanduidings vir bestuur, vir vrouens in loopbane en vir instansies, akademies en ander, wat daarin belangstel om verdere werk in hierdie navorsingsarea te doen.

S. -Afr. Tydskr. Bedrytsl. 1979, 10: 57-63
The rising aspirations of women to be business managers and leaders is a global phenomenon. Worldwide, the challenge for these aspiring women has been to groom themselves to climb the corporate ladder in their organizations and succeed at higher level jobs. All over the world business communities have responded, some more so than others, by establishing patterns of employment and by creating organizational climates in which their female manpower has been able to make a more meaningful contribution than they have done in the past.

The situation in South Africa is that there are critically few women in executive and management positions. Those who have aspired and achieved and are currently in responsible management positions are role models. As role models, these women provide valuable feedback for the future management development of South African women. By identifying these women, successful in an area that up to very recently was closed to them, by getting a better understanding and clearer perspective of their views and experiences, management and women can both benefit.

This article, based on replies received in a national survey of women who have management and executive status in corporations, presents an overview of South African women managers. In doing so it provides answers to several crucial questions: Who are they? How do they tend to think? What kind of work areas and habits do they have? How do they explain their own success and the failure of other women to reach the top, and what is important to them in their day-to-day working lives?

\section{The Survey - An Attempt to Discern trends}

There is no list of women managers in the country. In order, therefore, to present as representative a picture as possible of South African women in management, a complex research method had to be used.

A random sample of $\mathbf{2 0 0}$ quoted companies (excluding the mines and mining houses) was drawn from the Johannesburg Stock Exchange Year Book. These companies were phoned individually and names were obtained, usually from the personnel director or personnel manager in the firm, of the most senior ranking female manager in their company where they had more than one woman at this level all the relevant names were recorded. A manager was defined as 
anyone above supervisor level in a position of management status and responsibility. Of the 200 corporations phoned, over half - 109 in all - said they did not have women in management positions. The other 91 provided 156 names.

Of the 156 questionnaires mailed, 75 were returned within three months by business women in a variety of management and executive positions. Regarding the representativeness of the sample, replies were received from a broad spectrum of industries, doing business in industrial, consumer and service sectors and in manufacturing, wholesaling, and retailing, with employee numbers varying from $50-100$ to over 50000 persons. The 75 questionnaires were analysed and trends relevant from a management point of view are the basis of the report which follows. These trends could serve as useful indicators for management, for women in careers and for parties - academic and other - interested in continuing work in the research area.

\section{Their Background: A Demographic Profile}

Table 1 outlines the background of South African women managers as revealed in the survey. The data show that women of all ages have reached management positions in South African companies but that it is the 30-40 age group where they are most predominant.

A high proportion of the respondents, $84 \%$ in all, are English-speaking - $8 \%$ have Afrikaans as their home language and $8 \%$ use both. A striking feature of their demographic profile is that $25 \%$ of them are of foreign nationality. Although it is difficult to gauge the reason for this, it is possible that this phenomenon is the result of a female skills lag in the country.

Forty-seven per cent are either single, separated, divorced or widowed. Fifty-three per cent are married and $56 \%$ have children. Of those with children, only two have a child under four years of age; $31 \%$ have children who are over 18 ; and a third have only children over 16 years of age (one or more) at home. These facts suggest that to a large extent women with demanding dual household and career roles and therefore with full family responsibilities, especially those with young children, are not in jobs at the higher corporate levels in South African business.

About half the respondents have university degrees or diplomas $-47 \%$ in all. Of these, $37 \%$ have Business, Accounting or Economic degrees, 23\% undergraduate and $14 \%$ postgraduate.

\section{Their Work Area, Status and Span of Control}

Women in management positions in South Africa are working in a variety of activities in business. The greatest concentration of respondents in the survey though, is in the Finance area (16\%) - primarily in accounting, financial planning and credit management; Personnel (15\%); and Marketing (15\%) - mainly in advertising, merchandizing, product management and sales promotion. They are also quite well represented in Administration (10\%) and Branch Management $(7 \%)$, and to a lesser extent in Research and Development, Public Relations, General Management, Production, and in Consulting.

Their job titles, to some extent an indication of their level of status, although varying from firm to firm and between industries, are mainly: Manager (44\%), Officer/Official $(9 \%)$, Controller (7\%), Company Secretary and Assistant Company Secretary (7\%), and Accountant (7\%). Among the other titles
Table 1 Background of South African women managers

\begin{tabular}{|c|c|c|c|}
\hline Age & $\begin{array}{c}\% \text { of } \\
\text { Respondents }\end{array}$ & $\begin{array}{l}\text { Marital } \\
\text { status }\end{array}$ & $\begin{array}{c}\% \text { of } \\
\text { Respondents }\end{array}$ \\
\hline Under 30 & 8 & Married & 53 \\
\hline $30-40$ & 51 & Single & 24 \\
\hline $40-50$ & 24 & Divorced & 17 \\
\hline $50+$ & 17 & Widowed & 6 \\
\hline Education & $\begin{array}{c}\% \text { of } \\
\text { Respondents }\end{array}$ & $\begin{array}{c}\text { Home } \\
\text { Language }\end{array}$ & $\begin{array}{c}\% \text { of } \\
\text { Respondents }\end{array}$ \\
\hline \multicolumn{4}{|l|}{ Degree or } \\
\hline Some university & & Afrikaans & 8 \\
\hline education & 9 & Both & 8 \\
\hline No university & & Other & 0 \\
\hline education & 44 & & \\
\hline Nationality & $\begin{array}{c}\text { \% of } \\
\text { Respondents }\end{array}$ & & $\begin{array}{c}\text { \% of } \\
\text { Respondents }\end{array}$ \\
\hline South African & 75 & Have children & 56 \\
\hline Other & 25 & No children & 44 \\
\hline
\end{tabular}

respondents have are Executive Director, Assistant Vice President, Managing Director, Consultant, Editor, Adviser, Head of Department, and Head of Administration.

Most of these women managers, $59 \%$ in all, have traditional staff type jobs, while the remaining $41 \%$ are in line positions. Almost all report to senior members of staff in their organizations: $4 \%$ to chairmen, $23 \%$ to managing directors, $4 \%$ to divisional or executive directors, $8 \%$ to group managers, $12 \%$ to general managers, $33 \%$ to functional nıanagers, $1 \%$ to senior managers, $4 \%$ to assistant managers and the rest to other senior persons in their firms. Twenty per cent report to more than one person while the remaining $80 \%$ report directly to a single individual.

As many as $81 \%$ of the respondents have fewer than 20 people reporting to them, the majority of these having fewer than five people under their supervision. Sixteen per cent have no one reporting to them at all. These figures indicate that their span of control and power is somewhat limited and highlights a pattern typical of the traditional career patterns for women in business up to now. Many of the women managers interviewed have direct access to the chief executive in their corporation or divisions and many have stafftype functions. This, coupled with their limited span of control, could mean that to a large extent they are operating at a fairly senior level but in isolation. For as long as women remain out of the mainstream of organizational interaction and politics, upward mobility into decision making levels will be difficult for them - even for those with potential.

When asked if they had ever experienced problems supervising men, $79 \%$ of the respondents replied in the negative. Only $21 \%$ said they had, and explained that resentment or insecurity on the part of their male counterparts had resulted in unco-operative and disrespectful attitudes towards them. Most of these women, however, commented that they had experienced these problems only at the start of their careers as managers and that these problems had only occurred once or twice. A typical remark made was: 'Once the ice is broken you get better co-operation.' Quite a number said that knowledge and expertise on the job was an all- 
Table 2 Work Mobility Table

\begin{tabular}{lccc}
\hline $\begin{array}{c}\text { Period } \\
\text { (in years) }\end{array}$ & $\begin{array}{c}\text { Years } \\
\text { worked }\end{array}$ & $\begin{array}{c}\text { Years in } \\
\text { company }\end{array}$ & $\begin{array}{c}\text { Years in } \\
\text { present job }\end{array}$ \\
\hline $0-5$ & 7 & 47 & 87 \\
$6-10$ & 12 & 30 & 8 \\
$11-20$ & 44 & 10 & 4 \\
$20+$ & 37 & 13 & 1 \\
\hline
\end{tabular}

Note: Numbers in tables represent percentage of the total sample.

important requisite to ensure the co-operation of males at work. Some women reported that they had experienced problems in this regard with black men; others said that the resentment came from other women.

In spite of this, the majority of the respondents, $68 \%$ in all, feel that in general men resent a female boss and $53 \%$ feel that women too, prefer working for a male superior.

\section{Their Career Mobility and Future Prospects}

Apparently most of the respondents remain in one particular area of business for their working lives, but South African women managers have not, it seems, necessarily remained with one company throughout their working careers. Some $7 \%$ of the respondents started their careers as secretaries or personal assistants to either the managing director or chairman in their company, but for the most part women managers in the country have tended to climb the corporate ranks within one particular division.

A substantial number, $37 \%$, have worked for more than 20 years and $44 \%$ for between eleven and 20 years. Despite that, only $13 \%$ have been with their current companies for 20 years and $10 \%$ for between eleven and 20 years $-77 \%$ have been with their present organizations for less than ten years, and, of these, $61 \%$ for less than five years. Another significant aspect of their career profile is that $87 \%$ have been in their present jobs for five years or less and, of these, $34 \%$ for a year or less.

Details of the mobility of the respondents are shown in Table 2. The data presented indicate that despite long careers, women managers in South Africa appear to show mobile characteristics. They have not been with their companies or been in their present jobs for any length of time, compared with the total number of years they have worked.

This could be due to a number of different reasons - one reason could be the fact that women managers in this country have needed to change their work environment in order to get a management opportunity in business as it presented itself, and as business has become more aware of the whole issue. Later on in this paper the fact that many women feel that they would be forced to leave their present jobs in order to further their careers, will be discussed, lending credibility to this opinion.

These figures, coupled with the fact that $75 \%$ have had no previous management positions in their companies, probably confirm that women managers are not only an unusual but also a comparatively recent phenomenon in South Africa.

Half the respondents are aware of the criteria management use to judge their performance - the other half are either unaware or are only partly aware of what these criteria are. Formal appraisal methods like 'Management by Objectives' (MBO) and other performance evaluation systems were mentioned by $13 \%$ of the respondents; most of the other
Table 3 Salaries being earned

\begin{tabular}{lc}
\hline \multicolumn{1}{c}{ Annual salary } & $\begin{array}{c}\text { \% of } \\
\text { Respondents }\end{array}$ \\
\hline R 5999 and less & 3 \\
R $6000-$ R 6999 & 7 \\
R $7000-$ R 7999 & 19 \\
R $8000-$ R 9999 & 23 \\
R 10 000-R11999 & 21 \\
R12 000-R14 999 & 13 \\
R15 000-R17 999 & 7 \\
R18 000-R19 999 & 3 \\
R20 000+ & 3 \\
\hline
\end{tabular}

women mentioned that they thought they were judged on their performance at activities directly related to their jobs, or general criteria like productivity and efficiency, or on their relationship with other employees.

Seventy per cent of the respondents are pessimistic about their future chances of promotion in their companies. Asked what they considered to be their future prospects with their companies, $48 \%$ replied 'none' - some said there was a possibility of upward mobility although it was slight. Others said they would have to switch companies if they wanted to get a more senior managerial post. Typical remarks made were 'I've reached the highest level - I've nowhere to go', 'I've reached the top as far as this company is concerned', 'There is no possibility for advancement for me unless 1 leave'.

\section{Their Financial Status}

The annual salaries presented above are those earned by the respondents and they give an indication of what is presently being earned by South African women in management positions. What they earn does not vary noticeably either with their age, how long they have worked or been in their companies, or with their education level. The size of the company and the area in which they work, also do not seem to appreciably influence the size of their pay-cheque.

Salaries were reported to be the same as those earned by men doing the same job in their company or in the industry by about $40 \%$ of the respondents, and as less than that of their male counterparts by about $60 \%$ of the respondents. Those who are not being paid the same as men tend to be earning below R 10000 per annum.

Most respondents, $80 \%$ in all, get fringe benefits, mainly in the form of cars, pensions, medical aid, bonuses (Christmas and production), discounts on products and services sold by their companies, housing allowances, travel, entertainment and car expense allowances, overseas trips, extra leave and leave pay, and free parking.

Some $60 \%$ believe that these are the same as those of men in the industry and in their companies - about $40 \%$ say they receive less. Nonetheless, there is firm consensus among the respondents that, generally speaking, women are not being paid the same as men doing the same job $-72 \%$ agreed with this statement. There was consensus too, that salaries paid to women should be equal to those paid to men doing the same job $-91 \%$ agree with this sentiment.

Their Management Training, Experience and Views Fifty-three per cent of the respondents have been on management training programmes, $47 \%$ have not. The main type of training described was that aimed at sharpening their 
management and leadership skills mentioned by at least half of the business women who had had training. Other types of training mentioned were those devoted to improving job skills related to specific functional areas. A few respondents mentioned 'process training', directed at improving attitudes and personal attributes as opposed to skills.

No one mentioned 'female process training', designed to improve the attitudes and self-confidence of women and to assist them with problems related specifically to women in management. This type of training is frequently used in overseas countries.

A large part of the training sessions experienced by the respondents comprised short seminars between one day and one week in duration. The majority of training programmes attended were presented by the companies themselves - much fewer were run by consultants or other institutions.

At least $25 \%$ of the women who had had management training had done so by attending management courses offered by universities, colleges or professional associations. Many of these women had attended the courses on their own initiative.

Asked whether these training programmes had assisted them in their jobs, $10 \%$ of the respondents said 'no'. The other $90 \%$ agreed that such training had been valuable and mentioned various ways in which this had assisted them mainly that it had improved their management, job and interpersonal skills, technical knowledge and their perspective of the philosophy and goals of their organizations.

Their feelings, though, are that generally the management training offered by companies to their women staff is inadequate $-84 \%$ said so.

Less than $10 \%$ said they thought the training offered to women in business was sufficient. Over $90 \%$ of the respondents said they felt that if women were given management training it would improve their performance. There was as much consensus too, on the view that at this point in time, management programmes in South Africa should not be run separately for males and females, but should be run jointly.

Several recommendations were offered to improve existing training, of which those repeated most often were:

- generally giving more management training to women as part of a clearly defined career plan

- actively encouraging more women to set higher career goals for themselves and to appreciate the merits of management training

- determined effort by corporations to change the attitudes of their male employees to providing management training for women

- adopting training programmes to suit the needs of individuals - male or female

- giving women the same level of management training as their male peers, to assist them with their present jobs and in preparation for higher level jobs.

\section{Their Work Habits and Needs}

Most South African women of seniority in corporations appear to spend a substantial amount of their time at work. Of the sample, only $10 \%$ estimated that they work either on the job or on job-related activities for up to 40 hours a week, $47 \%$ said they work between $41-50$ hours a week, $36 \%$ reported to be putting in between 51-60 hours a week, and $7 \%$ said they work more than 60 hours on average. Asked whether they needed more time off from work than they got,
Table 4 Twelve factors rated in order of importance*

\begin{tabular}{lc} 
I Work factors & $\begin{array}{c}\text { \% of } \\
\text { Responses }\end{array}$ \\
\hline The work I do, is interesting & 92 \\
I get full responsibility and authority & 75 \\
I have promotion and growth opportunities in the company & 53 \\
My work is appreciated by my superiors & 51 \\
My salary and fringe benefits are good & 47 \\
I am involved in setting company policies and strategies & 35 \\
I have status & 35 \\
I have pleasant working conditions & 31 \\
I have job security & 30 \\
I agree with company policy and the way the company is & 28 \\
administered & 10 \\
I get understanding from my superiors when I have per- & \\
sonal problems & \\
There is sufficient discipline and supervision in the com- & \\
pany &
\end{tabular}

*Respondents were asked to choose the five factors they regarded as the most important.

$89 \%$ said 'no' - the rest said 'yes'. Those that want more time off said they need it for relaxation purposes, homerelated activities, and pursuing interests other than those related to their jobs.

Half the respondents feel that there are special facilities working women need from their companies that men don't need. Those mentioned most often were flexitime, child care services and maternity leave.

There apparently are still many companies which base their manpower policies and programmes on the mistaken notion that women, even those in high ranking positions, regard their jobs as hobbies, that they work out of economic necessity and thus are generally less committed to their companies. Women are believed to be more interested in what Herzberg called the 'hygiene factors' - money, security, working conditions and relationships in their companies ${ }^{1}$. Factors motivating men are regarded as more the intrinsic type, like achievement, responsibility and the work itself ${ }^{2}$.

In this study, respondents were asked to choose from a list of 12 factors, the five that were of greatest importance to them in their work. The results of what they said are shown in Table 4.

A look at the factors that these South African women managers consider as essential in their working environment suggests that they are, in fact, looking for interesting work, responsibility, an opportunity to move into higher ranks of management, and approval and recognition. In short, gaining acceptance and being in a stimulating environment where they can get ahead, seem to be of paramount importance to them.

The data confirm that these women do rate the intrinsic factors at work higher than the extrinsic, so much so in fact that this points to interesting observations for South African management.

The fact that most of these women are married and still rate salary, job security and working conditions relatively low, is significant in itself. An understanding of the facts that they need to be stimulated, involved and challenged in their work and need to be rewarded by being given recognition, status, and promotion and growth opportunities in their companies, is the basis on which South African management should develop their human resources policies to place 
and motivate the women in their employ in the future.

Especially important too is that these values and attitudes indicate those values which are appropriate for women who are not yet in management positions. The message both to management and to aspiring women is clear. South African women who have been successful tend to regard their work as a career rather than a money-making exercise. They also strongly recognize that women are as achievement-oriented as men. Sixty-eight per cent disagreed with the statement that 'women have less need than men to achieve in the working world'.

\section{To What They Attribute Their Own Success}

Repondents were asked to account for their success as working women. The factors mentioned most often by them were:

determination and drive

hard work

interpersonal skills

willingness to take on responsibility

self-confidence

enthusiasm

environmental support

extra effort

Repeatedly they said that their success was due to energy and dedication which surpassed that of their co-workers or which exceeded what was required of them. Comments made frequently were: 'I worked harder than anyone else', 'I always worked longer hours than anyone else', 'I did my job well - better than others!', 'I was willing to work harder for longer hours than was necessary'.

Quite a number of respondents referred to luck as playing a part in their careers with comments like 'I was in the right place at the right time', 'I happened to be around when the opportunity came my way'. Very few respondents attributed their success to a formal career plan, although one or two did mention that they had set themselves career goals.

\section{Personal Characteristics They Feel Are Needed For Success}

South African women, all of whom have succeeded in getting into senior management positions in the country, agree that there is a set of personal characteristics necessary to get to the top in business corporations.

The responses they gave were varied but there were eight characteristics given most often by them in response to the open-ended question put to them. Those attributes which they consider to be necessary for a person to advance into management in organizations are shown below. The list shows these characteristics and the percentage of women who mentioned them:

determination, drive, self-motivation $\quad 90$ competence, ability to do the job 46 self-confidence, guts and courage $\quad 36$ ability to take on responsibility 34 personality, pleasant disposition $\quad 30$ ambition

interpersonal skills

intelligence

They were then asked whether they felt that the essential characteristics which they had mentioned, differ between men and women $-27 \%$ of the respondents felt that they do.
The dominant theme in the examples given by the women who said that women needed different personal attributes to succeed at management, was that what women needed, was not so much difference from men but that they needed qualities which were more pronounced. Typical statements made were: 'Women need all these characteristics but to a larger degree', 'To be noticed, women have to be better', 'Women must be better than men in all abilities and personal qualities', 'Women have to be above average and have unquestionable ability'.

\section{Their Vlews On Barriers To Advancement For Women}

Judging from the responses of the women studied, there is a great deal of talent being wasted in corporations. Of the total example, 97\% said that at present there are women competent enough to assume higher level jobs, but who are not in these jobs. The reasons they gave for this were varied and numerous, but they tended to fall into these three categories:

- Management Attitudes. Unsympathetic and traditional attitudes leading to an 'invisible ceiling' for women and difficulty in breaking into the higher rewarding levels of business.

- Discrimination. 'Visible barriers' - a lack of opportunity, recognition and interest due to prejudice - no training or inclusion in job selection processes.

- Low Ambition. A lack of career direction or drive and limited ambition on the part of women themselves - they aim too low and are satisfied with mediocrity.

Respondents were also given five factors as those preventing women from performing in their companies and another five factors as those responsible for excluding women from top level jobs. In each instance they were asked to rank the factors from $1-5$ in order of importance. Their viewpoints are shown in Figure 2.

According to them a lack of motivation on the part of women to take on responsibility is the most serious factor inhibiting women's performance in corporations, coupled with the lack of opportunity to prove themselves. Rated most often as the second most important factor was a lack of adequate training for women. A lack of ability on their part was given as the most unimportant reason why women don't perform.

Discrimination against women and misunderstanding by management about women's ability were given as the factors most important in excluding women from top level jobs - poor performance by females so far, was rated as the least important contributor to the situation.

These responses, together with replies to other questions, confirm that the future of women in corporations will depend on their willingness to take on more responsibility, rather than on their ability to improve their competence on the job. Coupled with this is the need for attitudinal and policy changes within companies.

\section{Views on Discrimination}

Ninety-two per cent of the respondents affirmed their view that there is discrimination against women in business $-61 \%$ of the sample feel that discrimination is in fact actually preventing competent women from getting top level jobs. 


\section{FACTORS RESPONSIBLE FOR EXCLUDING WOMEN FROM TOP LEVEL JOBS}
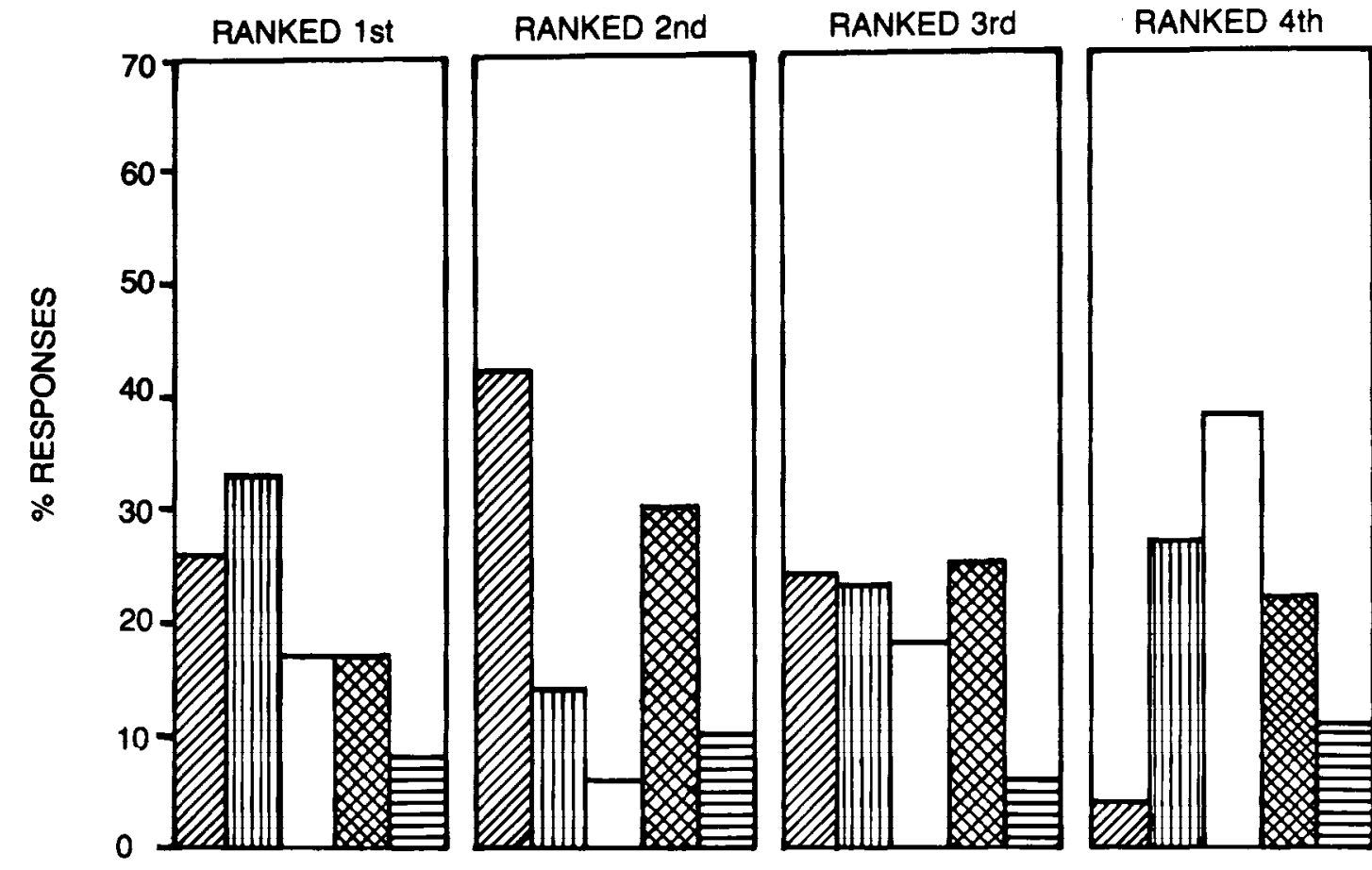

RANKED 5th

Misunderstanding by management about women's ability

Discrimination against women
Refusal by women to take on responsibility
Women's poor performance in the past

FACTORS PREVENTING WOMEN PERFORMING IN COMPANIES
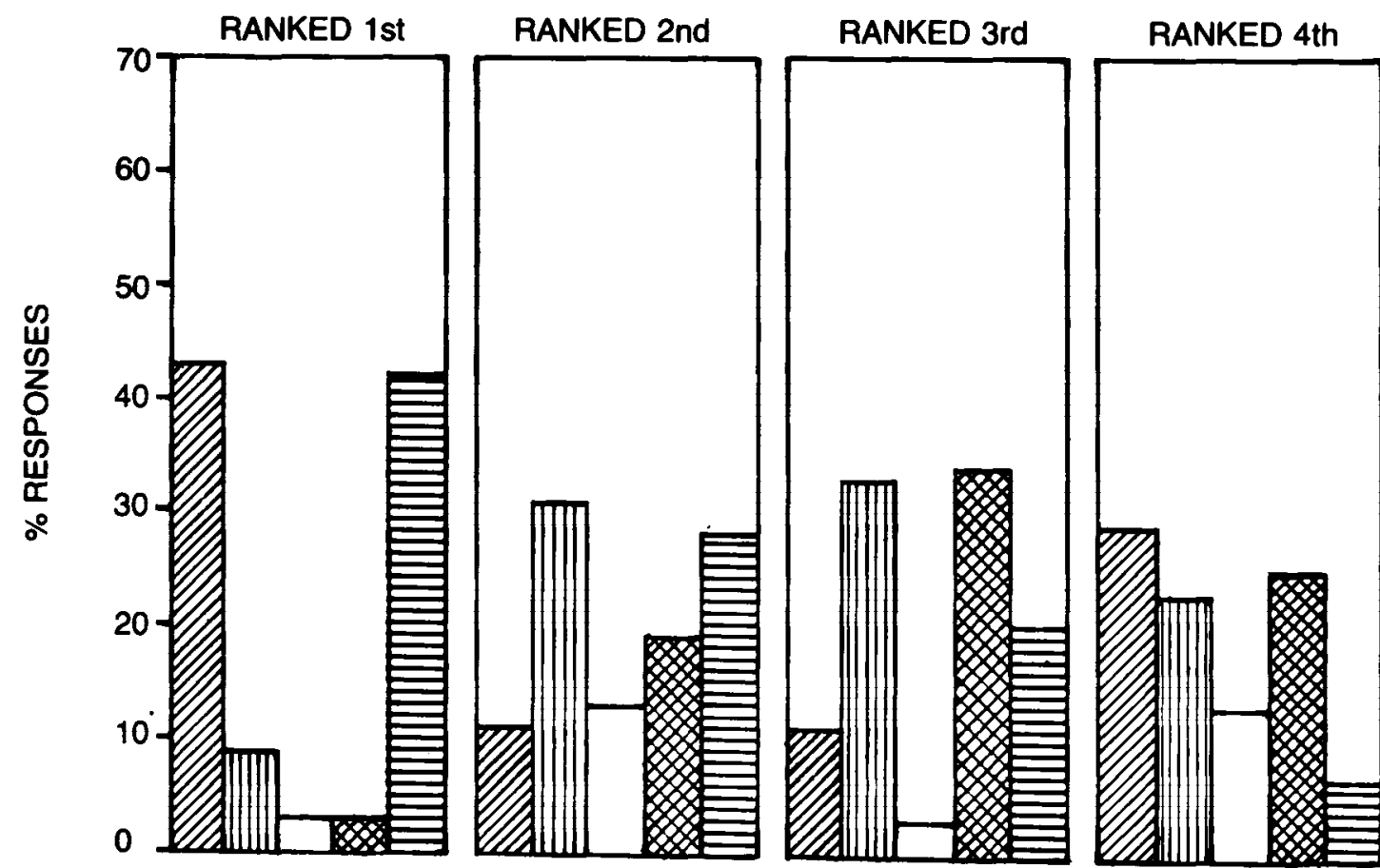

RANKED 5th

Lack of motivation on the part of women to take on responsibility
Lack of ability to do top level work
Lack of opportunity to prove themselves 
Asked whether they had personally ever experienced discrimination in the work situation. $52 \%$ said they had. The most serious types of discrimination that these women believe are being experienced most often by South African women in business are:

- fringe benefits

- being bypassed for promotion

- lack of opportunity and recognition

- being excluded from social activities and functions.

South African women managers agree that laws preventing discrimination against women in business will encourage more highly skilled women to work $-87 \%$ feel this way. They also feel that laws of this nature will get more highly skilled women into top level jobs - 59\% expressed this opinion.

In the open-ended question asking for factors they believe to be keeping competent women out of high level jobs in South Africa, the income tax system was mentioned by some respondents; asked directly in another question whether the tax system, as it affects married women, stops competent women from working, $44 \%$ gave a 'definite yes' response, $42 \%$ said 'probably yes' and $14 \%$ said 'no'. Fiftysix per cent of the respondents were adamant that if the tax system were changed in the country, more competent women would be willing to work in high skill job areas $33 \%$ said it was possible, while $11 \%$ disagreed with the proposition.

\section{Conclusions}

This study is an attempt to present a portrait of women in the country who have made it into the managerial ranks of business. Because they have done so without the support of laws and have often been successful despite the odds, they have gathered a great deal of experience along the way. Their views are therefore fundamental as guidelines for

- Companies embarking on affirmative action programmes

- Companies introducing career development for their women employees

- Companies designing training programmes for the future management development of women

- Companies working toward the better utilization of their human resources

- Women aspiring to positions of more seniority than they have had up to now.

Inevitably, as societal pressure increases in South Africa and women are more active in demanding equal job opportunities, management will have to integrate women into higher levels in their organizations. Women need to become more aware of their future career roles and the attitudes which traditionally have undermined their potential for management.

Changes made by corporations to accelerate female progression into higher levels of responsibility and decisionmaking in organizations, must be constructive, based on a better understanding of their womanpower. Policies and programmes must be designed not as short term or token gestures but as permanent - not only to the benefit of South African women and the individual companies with whom they are concerned, but also to the benefit of the South African economy and the quality of South African life.

\section{Future Research}

The data collected in this project have exposed some interesting trends and facts regarding South African women managers. These data should be viewed within the framework of the research method used and can no doubt be of value both in the market place and for future research.

To make the project even more meaningful, future energy could be put into comparing the statistics presented in this paper with those of South African male managers. Another avenue for future research could be work of a comparative nature either between industries or countries.

The fact, however that there is no list of women managers in the country or clear consensus as to a definition of 'manager', is a problem which needs attention and can only be solved when sufficient work is done in this area.

The future of research in the field of women and management is wide open in South Africa. Compared to other countries where this field of study has exploded as a research area, we have only just skimmed the surface.

\section{Notes}

This article is based on a comparative study done in Canada ${ }^{3}$ and South Africa, and being completed in Britain. The respective articles are written in order to facilitate a comparative analysis. In some cases, striking similarities were found between the South African and Canadian situations, while there are also some remarkable differences.

\section{Acknowledgements}

The author gratefully acknowledges the co-operation and effort of the companies and women managers who took part in the study. The contribution made by Mrs Cecily Smith to the research project over a period of 12 months, 1978-1979, and the funds and facilities provided by the Institute of Entrepreneurship and Management, Graduate School of Business, University of Stellenbosch, to undertake the project.

\section{References}

I HERZBERG, FREDERICK, One more time: How do you motivate employees, Harv. Bus. Rev. 46: 1, Jan/Feb 1968, pp. 53-62.

2 DITBOYE, ROBERT $\mathrm{L}$. Women as managers - stereotypes and realities, Surn. Bus. May/June, 1975, pp. 22-26.

3 VAN DER MERWE, S. A portrait of the Canadian Woman Manager, Business Quarterly, Autumn 1978, p. 45. 